\title{
CHALLENGES FACING THE OF TOURISM SPORT ACTIVITIES IN JORDAN
}

\author{
Issam Mohammad AL-MAKHADMAH* \\ Ajloun College, Al-Balqa Applied University, Tourism Management Department, Jordan, e-mail: isammakhadmeh@bau.edu.jo
}

\author{
Samer Fandi ABABNEH
}

Ajloun College, Al-Balqa Applied University, Tourism Management Department, Jordan, e-mail: Samerfandi2007@ bau.edu.jo

\author{
Khaled Moohammad ALRABABAH
}

Ajloun College, Al-Balqa Applied University, Head of Planning, Training and Quality Department, Jordan, e-mail: rb.khalid@bau.edu.jo

Citation: Al-Makhadmah, I.M., Ababneh, S.F., \& Alrababah, K.M. (2021). CHALLENGES FACING THE OF TOURISM SPORT ACTIVITIES IN JORDAN. GeoJournal of Tourism and Geosites, 37(3), 905-908. https://doi.org/10.30892/gtg.37322-724

\begin{abstract}
The purpose of this research is to identify challenges facing the tourism sport activities, identify the most important activities of tourism sport and proposed model for developing tourism sport activities in Jordan. The sample was consisted of 180 participants who living in Jordan. Data collection in this study was consisted of quantitative and qualitative. Quantitat ive and qualitative were administered in training camps and residential areas. Moreover, interviews were conducted with local community leaders. The results revealed that there are many challenges facing tourism sport activities such as weak infrastructure and the lack of qualified technical cadres to help tourists. The study came out with a set of recommendations, the most prominent of which is to work on overcoming the challenges facing tourist sport activities and taking into account the proposals put forth by experts to develop the tourism sport sector in Jordan.
\end{abstract}

Key words: Sports, Tourism, Challenge, Tourist Sport activities, Jordan

$* * * * * *$

\section{INTRODUCTION}

Tourism is a hospitality business, and they expect gracious and prompt service any time tourists visit any attraction (Kersulić et al., 2020; Hritz and Ross, 2010). If tourism deserves (Murphy, 1985: 133) its pseudonym of being hospitality in this regard, it must look beyond its own doors and staff and take into account the economic social, and cultural effects it has on the host community. It is therefore useful that tourism researches investigate the social effects of tourism on host communities as suggested by Fredline (2006). Sport tourism is one of the fastest growing market segments in the tourism industry, according to Kersulić et al., (2020), and is attracting improved attention for its environmental, economic and social effects on destinations. In comparison to previous research into tourism impacts, tourism as a whole has tended to focus primarily on tourism and does not distinguish between the various forms of tourism that might be present in the destination. Brunt and Courtney (1999) suggest that tourism's social and cultural effects should be taken into account in the planning process and in the process of environmental impact assessment, so that benefits are optimized and concerns minimized. The engagement of communities so that people realize tourism is an important general planning strategy for strengthening positive and mitigating negative impacts.

This can be accomplished by the involvement of the group in decision-making and the equal distribution of business benefits (Brunt and Courtney, 1999). In addition, an important planning and policy factor for the effective growth, promotion and implementation of current and future programs and projects is likely to be the expectations and attitudes of residents towards the effects of tourism. In Jordan, there are many types of sports tourism that are very popular in the world of sports in the region and the world (Wise et al., 2019; Perić et al., 2019; ALdmour et al., 2011).

There are different types of sports tourism, such as football games, water sports, diving, swimming, and other games that represent an important aspect of sports tourism in Jordan. Therefore, the purpose of this research is to identify challenges facing the tourism sport activities and proposed model for developing tourism sport activities in Jordan.

\section{LITERATURE REVIEW}

Sport tourism is one of the largest tourism patterns and expanding rapidly, according to Standeven and De Knop (1999: 36), and is attracting improved attention for its economic, social and environmental growth and advantages. It is commonly recognized that major sporting events greatly contribute to the economic growth and traffic of visitors in an area and are a critical component of the tourist destination marketing mix (Kersulić et al., 2020; Hritz and Ross, 2010). Numerous studies have been dedicated to recognizing and describing sports tourism.

Sport tourism, however, is described in this paper as all types of passive and active participation in sporting activity, involved casually or in an organized manner for business reasons that require travel from home and work locations

\footnotetext{
* Corresponding author
} 
(Standeven and De Knop, 1999: 12). Nyikana and Tichaawa (2020) seeks to examine the nature of sport and tourism interrelationships in Central Africa, using Cameroon as a case study area. The key findings indicate that the interrelationships between sport and tourism in this context are relatively weak, especially at the policy and planning levels, despite there being potential for strengthening of these at the local operational level for sustainable tourism development. Sport tourism is considered a medium for economic growth (Gibson, 1998).

The perceived economic impacts of particular sports tourism activities by community members have been investigated in previous studies. Boonsiritomachai and Phonthanukitithaworn (2019) and Perić et al., (2019) emphasized that one of the factors affecting tourism sports is the combined participation and awareness on how to improve the support of the local population for tourism sporting events. Several previous studies have sought to reveal the relationship between sport and tourism, (Kersulić et al., 2020; Wise et al., 2019; Perić, et al., 2018; Kranjčević, 2017) sporting events and activities contributed to the promotion of tourism activity.

According to Getz and Page (2016), the role of tourism sports to stimulate new forms of internal development, such as the renewal of infrastructure, building community, voluntary capacity, and improving marketing, which would bring new economic gains. Walo et al., (1996) indicated that an economic benefit from sporting activities was perceived by residents. Soutar and Mcheod (1993) analyzed the expectations of residents of Australia's America's Cup protection and discovered that the perceptions of residents before the case were strikingly different from the real social and economic impacts encountered. Garidzirai and Pasara (2020) aim to explore the role of tourism on economic growth.

The study outcomes show a positive association among infrastructure index, tourism receipts, number of local, international tourists and economic growth. Therefore, the study recommends that the factors of production be shifted to the tourism industry for high productivity. The real economic effects on the city were not as high as predicted, and the social costs of the event, such as traffic and pollution, were not viewed as an issue before the event (Soutar and McLeod, 1993). Although comprehensive in their analysis, studies have not looked challenges facing the tourism sport activities and proposed model for developing tourism sport activities.

\section{METHODOLOGY}

There were local people living within Aqaba and the surrounding area in the sample population. To choose the sampling units where most local people live, cluster sampling was applied. To recruit respondents from each sampling unit, simple random sampling techniques were applied. The collection of data was a mixture of questionnaires and interviews. In suburban areas, questionnaires and interviews were conducted (Rassel et al., 2020). Additionally, interviews with local community leaders were conducted. 180 respondents participated in the study in total. The data collected was arranged, tabulated and analyzed using the Social Science Statistical Kit (SPSS).

The study used research design for surveys. In addition, areas within Aqaba, which are highly frequented by sports tourists, were chosen for the study using purposeful sampling. Local community members, business community members and training managers were then recruited into the study using simple random sampling. This research used both secondary and primary data sources, gathering secondary information from written materials such as journals and books, while obtaining primary information from questionnaires and interview schedules. Furthermore, both descriptive statistics and inferential tests were carried out with the aid of the Statistical Kit for Social Science (SPSS).

\section{RESULT AND DISSCUSION}

To answer the first research question namely, what are the Challenges of sports tourism, the result can be seen on Table 1 below. In the result above all challenge variables had a mean more than 3.9 which indicates strong approval to positive social impacts associated with sport tourist in the region.

Table 1. Challenge Facing sports tourism

\begin{tabular}{|c|l|c|c|c|}
\hline $\mathbf{N}$ & \multicolumn{1}{|c|}{ Items } & $\mathbf{N}$ & Mean & $\begin{array}{c}\text { Std. } \\
\text { Deviation }\end{array}$ \\
\hline 1 & High cost & 180 & 4.51 & .901 \\
\hline 2 & $\begin{array}{l}\text { The lack of } \\
\text { infrastructure }\end{array}$ & 180 & 4.11 & .861 \\
\hline 3 & $\begin{array}{l}\text { The lack of appropriate } \\
\text { equipment for some } \\
\text { types of sports }\end{array}$ & 180 & 3.98 & .645 \\
\hline 4 & $\begin{array}{l}\text { The limited availability } \\
\text { of safety and security } \\
\text { elements for some types } \\
\text { of tourist sport }\end{array}$ & 180 & 3.96 & .784 \\
\hline 5 & $\begin{array}{l}\text { Insufficient number of } \\
\text { experts in the field of } \\
\text { tourism sport }\end{array}$ & 180 & 4.05 & .751 \\
\hline 6 & $\begin{array}{l}\text { The prevailing social } \\
\text { culture that prevents } \\
\text { some aspects of tourist } \\
\text { sport }\end{array}$ & 180 & 4.04 & .852 \\
\hline
\end{tabular}

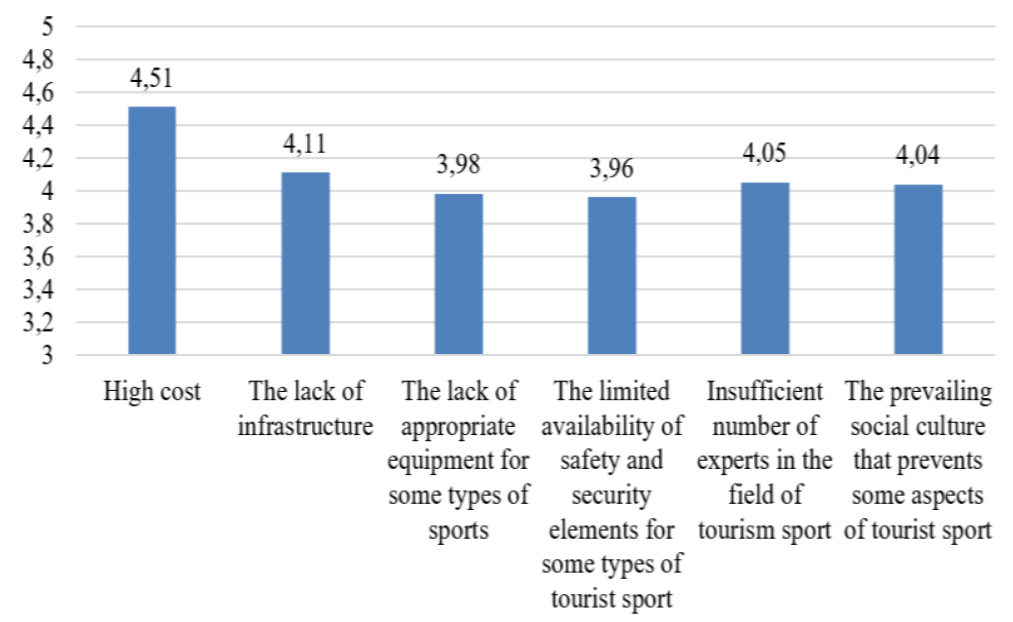

Figure 1. Challenge facing Sport Tourism 
Very strong means above 4.0 were scored on challenge variables including: cost (4.51), infrastructure (4.11), appropriate equipment (3.98), safety and security (3.96), experts (4.05) and social culture (4.04). The high cost is an important factor that affects the tourism sport in Jordan, followed by the lack of infrastructure.

To answer the second research question namely, what are the most important activities of tourism sport in Jordan? The result of mean and standard deviations can be seen on Table (2) below.

In the result above all important variables of sport tourist had a mean more than 3.11 which indicates strong approval to positive social impacts associated with sport tourist in the region. Very strong means above 4.0 were scored on challenge variables including: Water Sports (4.60), Jumping (4.10), Climbing (4.58), Bicycle Race (3.18), Skydiving (4.70) and Walking (3.11). The Water Sports is an important factor that affects the tourism sport in Jordan, followed by the Climbing.

To answer the third research question namely, what are the most important proposals for developing tourism sport in Jordan? The result can be seen on Table (3) below.

Table 2. The Most Important Variable

\begin{tabular}{|c|c|c|c|c|}
\hline $\mathrm{N}$ & Items & $\mathrm{N}$ & Mean & $\begin{array}{c}\text { Std. } \\
\text { Deviation }\end{array}$ \\
\hline 1 & Water Sports & 180 & 4.60 & .901 \\
\hline 2 & Jumping & 180 & 4.10 & .861 \\
\hline 3 & Climbing & 180 & 4.58 & .645 \\
\hline 4 & Bicycle Race & 180 & 3.18 & .784 \\
\hline 5 & Skydiving & 180 & 4.70 & .751 \\
\hline 6 & Walking & 180 & 3.11 & .852 \\
\hline
\end{tabular}

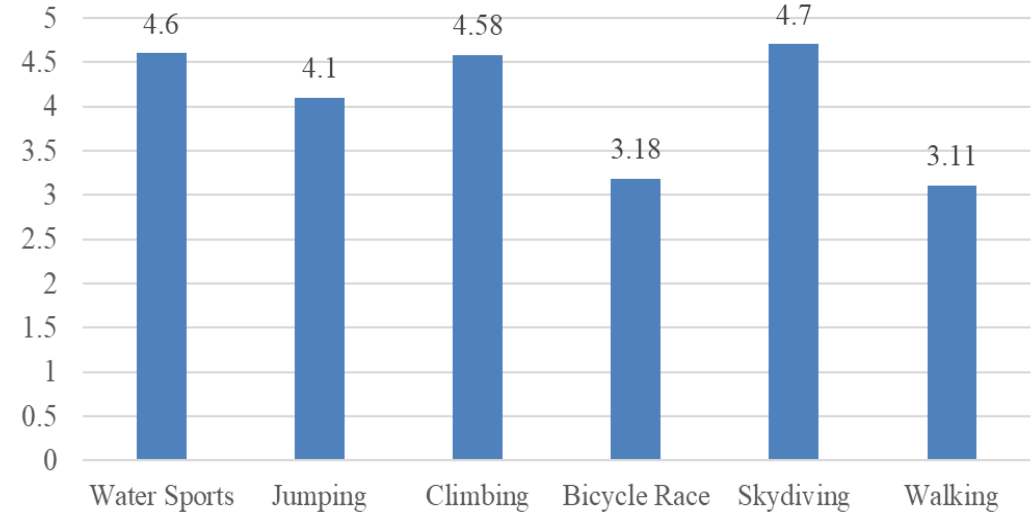

Figure 2. Important Variable

Table (3) introduce a number of proposals and suggestions to encourage tourism in Jordan. The table shows that $80 \%$ suggest creating the infrastructure for tourism as the highest percentage. Table 3 reveals that tourism obstacles in Jordan can be managed by developing the interest of tourism ant tourist activities. Also, it is very important to increase our awareness of sports role in tourism development.

Table 3. Proposals for developing tourism sport

\begin{tabular}{|c|c|c|}
\hline Suggested & Iterations & Percentage \\
\hline $\begin{array}{c}\text { Create the infrastructure } \\
\text { for tourism }\end{array}$ & 144 & $80 \%$ \\
\hline $\begin{array}{c}\text { Increasing the number of } \\
\text { technical cadres to } \\
\text { enhance the practice of } \\
\text { tourism sport activities }\end{array}$ & 128 & $71 \%$ \\
\hline $\begin{array}{c}\text { Awareness of the most } \\
\text { important tourist sport } \\
\text { facilities in Jordan }\end{array}$ & 120 & $67 \%$ \\
\hline $\begin{array}{c}\text { Promotion of tourism } \\
\text { sport activities in Jordan. }\end{array}$ & 114 & $63 \%$ \\
\hline
\end{tabular}

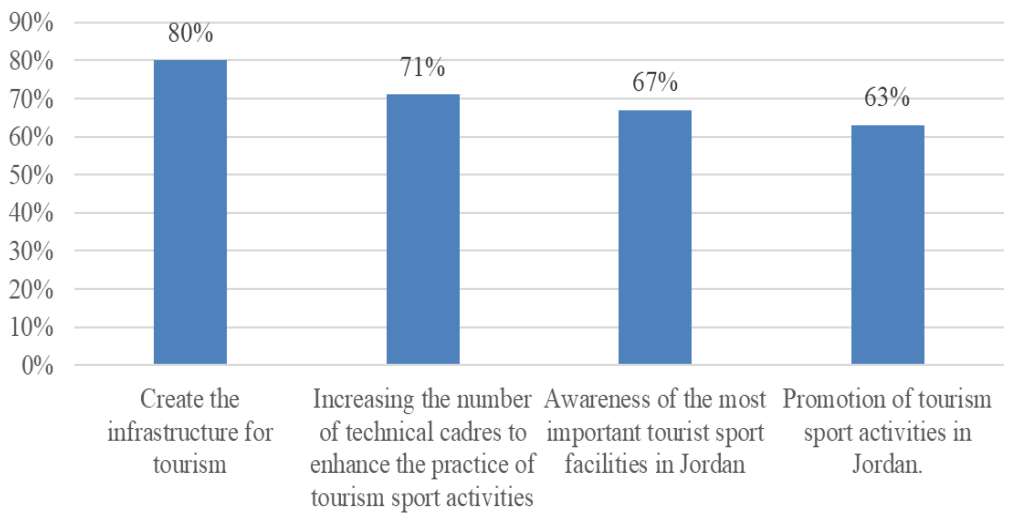

Figure 3. Proposals for Developing Tourism Sport

\section{DISCUSSION}

The results endorsed the social and indicated that the economic benefits seem to have the greatest effect on whether local people support the creation of more sport tourism. This can be due to the belief of people that tourism can provide alternative sources of revenue, expanded business operations, and improved livelihoods in general.

In addition, in order to earn the financial benefit from the sports tourist dollars, people appeared able to ignore any negative social impacts. Recognizing that social effects are substantially equal to economic benefits, tourism planners should track resident quality of life problems, which can contribute to resident-friendly initiatives (Kersulić et al., 2020; Wise et al., 2019; Perić et al., 2019; Hritz and Ross, 2010). These writers state that people who frequently use tourist attractions view them more as leisure amenities for the city. A balance must be developed between the social, environmental and economic aspects of sports tourism because the study of the quality of life of residents in tourist places is reflected in the methods of attracting sports tourism. It should be noted that the water sports are an important factor that affects the tourism sport in Jordan, followed by the climbing, and the high cost is an important factor that affects the tourism sport in Jordan, followed by the lack of infrastructure. 


\section{CONCLUSION}

This research offers a more concise picture of what particular kinds of effects affect the promotion of sports tourism. The findings revealed that economic impacts remain a key factor behind development funding.

This study examined the perceived effects of sports tourism by analyzing the attitudes of residents towards sports tourism at their destination. The participants were funded by general sports tourism. As powerful predictors for funding, these variables also contributed. Therefore, tourism planners ought to adapt their decisions to the needs of the community (Kersulić et al., 2020; Hritz and Ross, 2010). This will boost the support of the community, which is an important ingredient for the success of the destination's sports tourism.

\section{REFERENCES}

ALdmour, H.A., ALsarayreh, M.N., \& Jawabreh, O.A. (2011). The role of sports events in the revitalization of touristic movement from the perspective of the tourist (golden triangle case study). Research Journal of International Studies-Issue, 1 (21), $159-168$. https://www.researchgate.net/profile/Mohammad-Alsarayreh/publication/324976883

Boonsiritomachai, W., \& Phonthanukitithaworn, C. (2019). Residents' support for sports events tourism development in Beach City: The role of community's participation and tourism impacts. Sage Open, 9 (2), 1-15. https://doi.org/10.1177/2158244019843417

Brunt, P., \& Courtney, P. (1999). Host perceptions of sociocultural impacts. Annals of tourism Research, 26 (3), $493-515$. https://doi.org/10.1016/S0160-7383(99)00003-1

Fredline, E. (2006). Host and guest relations and sport tourism. Sport in Society, 8 (2), $263-279$. https://doi.org/10.1080/17430430500087328

Getz, D., \& Page, S.J. (2016). Progress and prospects for event tourism research. Tourism management, 52 (1), $593-631$. https://doi.org/10.1016/j.tourman.2015.03.007

Gibson, H.J. (1998). Active sport tourism: who participates? Leisure studies, 17 (2), 155-170. https://doi.org/10.1080/026143698375213

Hritz, N., \& Ross, C. (2010). The perceived impacts of sport tourism: An urban host community perspective. Journal of sport management, 24 (2), 119-138. https://doi.org/10.1123/jsm.24.2.119

Kersulić, A., Perić, M., \& Wise, N. (2020). Assessing and considering the wider impacts of sport-tourism events: a research agenda review of sustainability and strategic planning elements. Sustainability, 12 (11), 4473-4485. https://doi.org/10.3390/su12114473

Kranjčević, J. (2017). The relation between sport and tourism at the beginning of tourism development-the case of Croatia. European Journal of Tourism Research, 16 (1), 19-31. https://ejtr.vumk.eu/index.php/about/article/view/275

Murphy, P.E. (1985). Tourism: A community approach. New York: Methuen.

Nyikana, S., \& Tichaawa, T. (2020). Revisiting Sport and Tourism Interrelationships: The Case of Cameroon. GeoJournal of Tourism and Geosites, 29, 756-771. https://doi.org/10.30892/gtg.29214-489

Perić, M., Đurkin, J., \& Vitezić, V. (2018). Active event sport tourism experience: the role of the natural environment, safety and security in event business models. International Journal of Sustainable Development and Planning, 13 (5), $758-772$. https://doi.org/10.2495/SDP-V13-N5-758-772

Perić, M., Vitezić, V., \& Mekinc, J. (2019). Comparing business models for event sport tourism: case studies in Italy and Slovenia. Event Management, 23 (3), 379-397. https://doi.org/10.3727/152599518X15403853721466

Rassel, G., Leland, S., Mohr, Z., \& O’Sullivan, E. (2020). Research methods for public administrators. $7^{\text {th }}$ Edition, New York, Routledge.

Garidzirai, R. \& Pasara, M.T. (2020). An Analysis of the Contribution of Tourism on Economic Growth in South African Provinces: A Panel Analysis. GeoJournal of Tourism and Geosites, 29(2), 554-564. https://doi.org/10.30892/gtg.29214-489

Soutar, G.N., \& McLeod, P.B. (1993). Residents' perceptions on impact of the America's Cup. Annals of Tourism Research, 20 (3), 571582. https://doi.org/10.1016/0160-7383(93)90010-Z

Standeven, J., \& De Knop, P. (1999). Sport Tourism. Champaign, IL: Human Kinetics.

Walo, M., Bull, A., \& Breen, H. (1996). Achieving economic benefits at local events: A case study of a local sports event. Festival Management and Event Tourism, 4 (3-4), 95-106. https://doi.org/10.3727/106527096792195353

Wise, N., Perić, M., \& Đurkin, J. (2019). Benchmarking service delivery for sports tourism and events: Lessons for Gorski Kotar, Croatia from Pokljuka, Slovenia. European Journal of Tourism Research, $22 \quad$ (1), $107-128$. https://ejtr.vumk.eu/index.php/about/article/view/378

Article history: Received: 06.05.2021 Revised: 22.07.2021 Accepted: 31.08.2021 Available online: 21.09.2021 